\title{
Diagnosis Effectiveness of Teaching Physical Education Curriculum 2013 for Sport and Health
}

\author{
Saputro \\ Universitas Negeri Surabaya, Indonesia \\ dwicatur58@yahoo.com.id
}

Pramono

Universitas Negeri Malang, Indonesia

pramono.fip@um.ac.id

\author{
Nurhasan \\ Universitas Negeri Surabaya, Indonesia \\ nurhasan007@yahoo.com \\ Suroto \\ Universitas Negeri Surabaya, Indonesia \\ suroto@unesa.ac.id
}

\begin{abstract}
This research was conducted with the aim to understanding problems and needs of teachers PJOK through need assessment (analysis of needs). This study was to determine the effectiveness of learning PJOK for Curriculum 2013. This study used quantitative and qualitative research design. Quantitative research is focused on the 10 learners and teachers Physical Education (PJOK) through video recording by looking at the amount of time learners or the so-called Academic Learning Times (ALT). Whereas qualitative research by providing questions to a questionnaire given to 54 teachers who implement Curriculum 2013 PJOK who are willing to fill out a questionnaire and interviews covered the spread in Master Learner PJOK SD. Engineering sample selection using purposive sampling. The sample is based on destination and availability of samples for examination. Data shows that: (1) the teachers too long, do break (B) with an average percentage of $27,4 \%$; (2) while warming (WU) with an average percentage of $2.22 \%$; (3) explain the rules (R) with an average percentage of $11.33 \%$; (4) practice skills (P) with an average percentage of $0.8 \%$; (5) exercise (S) with an average percentage of $11.11 \%$; (6) do the game (G) with an average percentage of $7.48 \%$. While the views of the Learner's Involvement Level: (1) the waiting time (W) learners with an average percentage of $28.51 \%$; (2) when there is no task (OFF) by an average percentage of $2.22 \%$; (3) a motion that is not appropriate (MI) with an average percentage of 3,03\%; and (4) the time to support the motion (MS) with an average percentage of 5.78\%. The total of all video recording and learners' activity for 135 minutes. From the results of questionnaires and interviews with teachers and teacher learner PJOK SD with the following data: (1) scientific or thematic learning model to be applied to the subject integrated PJOK of 54 teachers is quite difficult to answer $3055.59 \%, 10$ difficult $18.52 \%$, and 14 is $29.92 \%$; (2) learning PJOK expected of 54 teachers, learners are active $(42 / 77.8 \%)$, simple $(35 / 64.8 \%)$ and healthy $(32 / 59.3 \%)$; (3) the need for the development of scientific or thematic models for subject PJOK elementary school of 54 teachers that 24 urgently need $44.44 \%, 27$ require $50 \%$ and 3 quite require 5.56\%; (4) PJOK teachers rarely use the strengthening of the use of scientific approach; (5) teachers tend rarely to apply the model of scientific learning in the learning process PJOK because too complicated. Teachers seek learning model that is simple and easy; and (6) the difficulties faced by teachers, among others understand the basic competence, choose the model, and learning methods. Based on the above data, we need a breakthrough or development of a particular learning model curriculum PJOK nuanced, 2013.
\end{abstract}

Keywords: learning effectiveness, PJOK, curriculum 2013

\section{INTRODUCTION}

Physical Education Sport and Health (PJOK) is a typical subject and unique in facing national education and growing. PJOK contribute to national education, dignified and meaningful while enhancing all forms of education destination domain, namely the domain of attitudes, knowledge, and skills. The purpose PJOK for formal schooling which reads material PJOK physical education and sport studies are intended to form the character of learners to be healthy physically and mentally, and foster a sense of sportsmanship. The aim should be accompanied PJOK responsibility and the role of the teacher in teaching PJOK in learners.

Characteristics of learning PJOK by Ates \& Eryilmasz (2011) \& Paturusi (2017) there are three key words of PJOK namely: motion, joy, and learning. The kids liked the move and love to learn. For learners motion solely for pleasure with the aim that learners are able to get used to an active life in sports both inside and outside the school. The motion is in learning PJOK not driven by the intent and specific purpose, such as forming an athlete skilled and accomplished, but formed learners as human beings who have the quality of motion normal, healthy life, discipline, self-confident, responsible and understanding broad. To achieve this, teachers PJOK need to plan, process, and effective supervision.

PJOK based learning curriculum of the 21st Century, known Curriculum 2013 has the characteristics of learning interactive, inspiring, fun, challenging, and motivating learners to actively participate and provide enough space for innovation, creativity, and independence. Lessons in accordance with the curriculum in 2013 required an effective learning process. The purpose of effectively is the goal of learning is achieved, as well as attitudes, knowledge, and psychomotor.

According to Rink (2013) one indicator of the effectiveness of learning, a teacher PJOK can be seen from the performance scores of students. Measurement of the effectiveness of learning in PJOK subjects can be assessed from the allocation of student time during the learning process, known PJOK Academic Learning Times (ALTPE) (Sari \& Hartati, 2013; Derri, et. al., 2008). According to Scruggs (2008) measured the effectiveness of based on the number of steps for conducting the activities of the motion or so-called Moderate to Vigorous Physical Activity (MVPA). In addition to several experts in the above, there is also the effectiveness developed by Sanders of the Value-Added Modeling (VAM) (Stenescu, 2013). 
According to NASPE (2010) to measure the effectiveness of learning through instruction, evidence of student learning, management, climate class and professionalism. Based on some of the experts in the above, it can be concluded that the effectiveness of learning PJOK can be measured based on the process and the results of all activities of learners through the level of innovation and creativity of teachers in choosing models, approaches, methods and learning strategies.

The effectiveness of learning required a teacher's ability to understand PJOK the nature, purpose and principles of learning PJOK. According to Husain, et. al. (2015) that the teacher is a factor most important in ensuring the learning process. Therefore, the first PJOK teachers understand the learning core knowledge. Core knowledge in teaching, is the knowledge of the competency of teachers to implement the learning process. Teachers PJOK also strived to have elements of: (1) the content of knowledge; (2) basic knowledge of pedagogy; (3) pedagogical content knowledge; (4) knowledge and curriculum; (5) knowledge in the context of learning; (6) knowledge and characteristics of learners; and (7) knowledge in effective learning objectives, exciting, and motivating learners to participate in activities PJOK.

The effectiveness of learning required an interesting learning breakthrough and cutting-edge, so as to develop and motivate learners to learn (Stanescu, 2012). Breakthroughs are expected to raise the learning development of human resources or learners in Indonesia. The data prove that the activity or participation of students learning time PJOK in Indonesia is still low or not ranked in the list Program for International Student Assessment (PISA), the data is still far less than the first ranked country of Hungary. The learning process also draws on the knowledge that is Higher Order Thinking Skills (HOTS) like activity remember, understand, apply, analyze, evaluate, create or develop. Data shows that science, reading and counting of learners in Indonesia is still low, as evidenced Indonesia ranks 64th out of 72 countries for Program for International Student Assessment (PISA). Related domains to subject PJOK skills are skills that concrete, that is follow-motor abilities.

Based on theoretical analysis and empirical analysis above, the process of learning effectiveness PJOK needs a diagnosis, so the researchers were able to help teachers PJOK developed a breakthrough in organizing learning. Teachers PJOK need to apply the learning that is based on short- and long-term objectives of the organization of the learning process PJOK teacher. Models, approaches, methods, learning strategies developed by teachers PJOK expected to develop the attitudes, knowledge, and skills of learners and organize effective learning.

\section{METHODS}

This study uses quantitative and qualitative research design. Quantitative research is focused on the 10 learners and teachers PJOK. Of the 10 learners in the analysis through video recording by looking at the amount of time learners or the so-called Academic Learning Times (ALT). Whereas qualitative research by providing questions to a questionnaire given to 54 teachers who implement Curriculum 2013 PJOK who are willing to fill out a questionnaire and interviews covered the spread in Master
Learner PJOK SD. Engineering sample selection using purposive sampling, the sample is based on the purpose and the availability of samples for examination. Characteristics of the sample in quantitative research that is 5 learners who have liveliness and 5 learners who are less active in the classroom. The data analysis is descriptive statistics by analyzing the data central tendency (average) for the quantitative and qualitative techniques that aim to make sense of phenomena or facts in depth. Used for data processing data analysis with a formula average (mean) as follows.

$\bar{X}=\frac{\sum X}{n}$

Note:

$\bar{X}=$ The average time for the entire sample

$\sum X=$ The number of times of the learning activities of all samples $\mathrm{n}=$ number of samples

To determine the percentage of time the number of learners using the following formula.

$P=\frac{\bar{X}}{\sum X}$

$\mathrm{P}=$ Percentage

$\bar{X}=$ The average time for the entire sample

$\Sigma \mathrm{X}=$ Total time of learning

\section{RESULTS}

Based on the data collected from the study questionnaire to elementary school teachers can be summed up with the following data. The learning model for integrated thematic scientific or applied to subject PJOK of 54 teachers is quite difficult to answer $3055.59 \%$, 10 difficult $18.52 \%$, and 14 is $29.92 \%$. Learning PJOK expected of 54 teachers, learners are active $(42 / 77.8 \%)$, sample $(35 / 64.8 \%)$ and healthier $(32 / 59.3 \%)$. Needs scientific model development or thematic lesson PJOK elementary school of 54 teachers that 24 urgently need $44.44 \%, 27$ require $50 \%$ and 3 quite require $5.56 \%$.

Researchers also conducted data SD PJOK Learner Teacher interviews in East Java first wave using a questionnaire and checklist through google via online form with the following data. PJOK teachers rarely use reinforcement use a scientific approach.; Teachers tend rarely to apply the model of scientific learning in the learning process PJOK because too complicated. Teachers seek learning model that is simple and easy. And the difficulties faced by teachers, among others understand the basic competence, choose the model, and learning methods.

Researchers in observing the learning process teachers use the instrument and format PJOK Academic Learning Times for Physical Education (ALT-PE), which consists of two variables: Context Level and Level Learner's Involvement with the translation of the subvariables and indicators. ALT-PE is one of the tools used to measure the effectiveness of learning PJOK (Rink, 2013). ALT-PE is used to analyze the way through the video recording PJOK teacher learning process. Then the researchers analyzed the activity or activities of 10 learners based on teacher observation of the attitude of learners unruly, with the following data (Table 1). Description codes ALT-PE as shown below (Table 2). 
Table 1

Students Learning Time (ALT-PE)

\begin{tabular}{|c|c|c|c|c|c|c|c|c|c|c|c|c|c|}
\hline Indi & A & $B$ & C & $D$ & E & $\mathrm{F}$ & G & $\mathrm{H}$ & 1 & J & Jumlah & Mear & Persen \\
\hline $\mathrm{T}$ & 0 & 0 & 0 & 0 & 0 & 0 & 0 & 0 & 0 & 0 & 0 & 0 & \\
\hline M & 0 & 0 & 0 & 0 & 0 & 0 & 0 & 0 & 0 & 0 & 0 & 0 & \\
\hline$B$ & 37 & 37 & 37 & 37 & 37 & 37 & 37 & 37 & 37 & 37 & 370 & \begin{tabular}{|l|}
37 \\
\end{tabular} & $27,40^{\circ}$ \\
\hline wu & 3 & 3 & 3 & 3 & 3 & 3 & 3 & 3 & 3 & 3 & 30 & 3 & 2,222: \\
\hline $\mathrm{TN}$ & 0 & 0 & 0 & 0 & 0 & 0 & 0 & 0 & 0 & 0 & 0 & 0 & \\
\hline ST & 0 & 0 & 0 & 0 & 0 & 0 & 0 & 0 & 0 & 0 & 0 & 0 & \\
\hline$R$ & 17 & 17 & 11 & 16 & 15 & 16 & 16 & 14 & 15 & 16 & 153 & \begin{tabular}{|l|}
15,3 \\
\end{tabular} & 11,33 \\
\hline SB & 0 & 0 & 0 & 0 & 0 & 0 & 0 & 0 & 0 & 0 & 0 & 0 & \\
\hline BK & 0 & 0 & 0 & 0 & 0 & 0 & 0 & 0 & 0 & 0 & 0 & 0 & \\
\hline$p$ & 2 & 2 & 1 & 2 & 0 & 1 & 1 & 1 & 1 & 1 & 12 & 1,2 & 0,888 \\
\hline $\mathrm{s}$ & 17 & 17 & 16 & 16 & 15 & 16 & 14 & 14 & 12 & 13 & 150 & 15 & 11,11: \\
\hline $\mathrm{G}$ & 10 & 10 & 10 & 9 & 9 & 10 & 11 & 10 & 11 & 11 & 101 & 10,1 & 7,4814 \\
\hline$F$ & 0 & 0 & 0 & 0 & 0 & 0 & 0 & 0 & 0 & 0 & 0 & 0 & \\
\hline 1 & 0 & 0 & 0 & 0 & 0 & 0 & 0 & 0 & 0 & 0 & 0 & 0 & \\
\hline$w$ & 37 & 37 & 36 & 37 & 38 & 40 & 37 & 37 & 44 & 42 & 385 & 38,5 & 28,518 \\
\hline $\mathrm{OF}$ & 3 & 3 & 3 & 3 & 3 & 3 & 3 & 3 & 3 & 3 & 30 & 3 & 2,222: \\
\hline ON & 0 & 0 & 0 & 0 & 0 & 0 & 0 & 0 & 0 & 0 & 0 & 0 & \\
\hline MA & 0 & 0 & 0 & 0 & 0 & 0 & 0 & 0 & 0 & 0 & 0 & 0 & \\
\hline MI & 1 & 1 & 12 & 3 & 8 & 0 & 4 & 9 & 3 & 0 & 41 & 4,1 & 3,03: \\
\hline MS & 8 & 8 & 6 & 9 & 7 & 9 & 9 & 7 & 6 & 9 & 78 & 7,8 & 5,777 : \\
\hline$\pi$ & 135 & 135 & 135 & 135 & 135 & 135 & 135 & 135 & 135 & 135 & & 135 & \\
\hline
\end{tabular}

Table 2

The Format and Concept of ALT-PE (Derri, et. al. 2008)

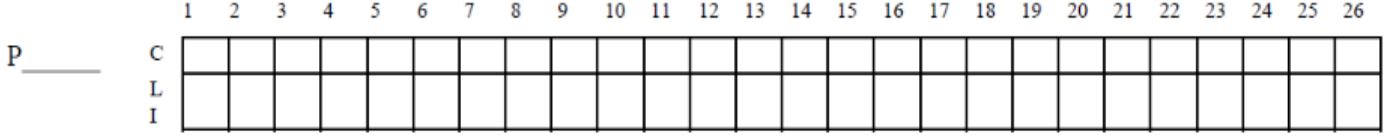

$\mathrm{P}=$ Pupil

$\mathrm{C}=$ Context of the interval

LI = Level of involvement of pupil

Context Level (C)

General content Subject matter knowledge

Transition (T) Technique (TN)

Management (M) Strategy (ST)

Break (B)

Warm-up (WU)
Rules (R)

Social behaviour (SB)

Background (BK)
Subject matter motor

Skill practice $(\mathrm{P})$ Scrimmage/routine (S)

Game (G)

Fitness (F)

\begin{abstract}
Learner involvement level (LI)
Not motor Motor engaged engaged

Interim (I)

Waiting (W)

Off-task (OF)
\end{abstract}

On-task (ON)

Cognitive $(\mathrm{C})$
From the table above it can be seen from the context Level: (1) teachers too long, do break (B) with an average percentage of $27,4 \%$; (2) while warming (WU) with an average percentage of $2.22 \%$; (3) explain the rules (R) with an average percentage of $11.33 \%$; (4) practice skills $(\mathrm{P})$ with an average percentage of $0.8 \%$; (5) exercise (S) with an average percentage of $11.11 \%$; and (6) do the game (G) with an average percentage of $7.48 \%$. While the views of the Learner's Involvement Level: (1) the waiting time (W) learners with an average percentage of $28.51 \%$; (2) when there is no task (OFF) by an average percentage of $2.22 \%$;
(3) a motion that is not appropriate (MI) with an average percentage of 3,03\%; and (4) the time to support the motion (MS) with an average percentage of $5.78 \%$.

\section{DISCUSSION}

Learners motion purely for pleasure. With the pattern of motion activity, learners are able to get used to an active life in sports both inside and outside the school. Motion learning concept is the basis for the implementation of the learning process and or experience repeated motion. The nature and definition of the motion learning are a very 
useful aid for teachers PJOK. According Cuerda (2015) instructional motion is a series of processes relating to the debriefing of experiences that will lead to changes in the ability of individuals to be able to show that skilled movements. In learning theory Piaget correlates between motor development and human knowledge. Where human development and maturation will affect the level of knowledge (cognition) human.

According to the opinion of Haapala (2016) regular participation in physical activity (motion) will create a higher fitness level was associated with an increase in academic and performance of the brain, such as attention and memory. These brain functions are the basis for learning. Learners who participate in physical activity were able to stay focused and stay on task learning, thereby enhancing the learning experience of students.

Data prove to the participation of learners during learning in physical activity by American Heart Association, learners are involved in at least 60 minutes of physical activity every day and at least 30 minutes should be in school (Budiyanto, et. al. 2016). Activity and participation of students during the school influenced the level of ability of schools and teachers in making policies that support learners to move the motion as a way of daily life (life style), as well as teachers are required to be teachers who are competent in providing the experience of motion meaningful learning PJOK.

Teachers need to learn and understand PJOK some things which are characteristic of the curriculum, how to learn, and the characteristics of learners. According to Barkoukis, et. al. (2014) in identifying learning styles and characteristics of learners, teachers PJOK in designing the learning process must consider the principles, creating motivation of learners, so that the learning process without the instruction of a teacher, students to continue to participate in physical activity.

PJOK teacher's ability to understand the nature, purpose and principles PJOK learning will affect the level of learning effectiveness. According to Husain, et. al. (2015) that the teacher is a factor most important in ensuring the learning process. Therefore, teachers must first understand the core knowledge of learning. Core knowledge in teaching, is the knowledge of the competency of teachers to implement the learning process. Teachers should have an element of: (1) the content of knowledge; (2) a basic knowledge of pedagogy; (3) pedagogical content knowledge; (4) knowledge and curriculum; (5) knowledge in the context of learning; (6) knowledge and characteristics of learners; and (7) knowledge in effective learning objectives, exciting, and motivating learners to participate in activities PJOK.

PJOK effective implementation of learning the necessary understanding of the characteristics of the curriculum and teachers' skills (pedagogy) teacher in the learning process of learners. According to Rink (2013) one indicator of the effectiveness of learning, a teacher PJOK can be seen from the performance scores of students. Learner performance can be assessed on how vigorously to make the participation of students during the learning process.

Teachers PJOK before determining and developing learning models need to understand the characteristics of the curriculum, how to learn, and the characteristics of learners so that learning will be meaningful and increase the participation of learners to move. According to Ibrahim (2015) that the learning model is a way of doing something that means the explicit presentation of a reality, for a pattern that organizes the normative relationship. Models can be defined as a pattern used in preparing the curriculum, designing and delivering materials, organizing learning, and selecting media and methods in a learning condition. The model describes the broadest level of teaching practices which contains the orientation of teaching philosophy.

Of the many models that have been developed, all models have the characteristics and the syntax is different and each has its own advantages, but on one hand, these models also have weaknesses. PJOK learning model development is needed by learners. According Stanescu (2012) to increase the interest of students in learning to PJOK lesson, teachers need to apply the model, new methods and means of teaching and learning activities, so that the contents of the learning will be more attractive. In developing learning models PJOK teachers need to understand other learning models. Joyce and Weil (2016) that if you want to develop a model of learning, it requires multidimensional thinking which means, among curriculum, the material characteristics and some models can be collaborated to meet the goals of learning. If developing models, so teachers can collaborate on some models of learning. Teaching models available as a reference and comparators PJOK teachers to develop.

Related learning model that already suggestion in the Regulation of Minister of Education and Culture Number 22 Year 2016 regarding the Standards of Elementary and Secondary Education Processes, according to the model curriculum in 2013 there are some models are already used and developed specifically subject PJOK. The learning model has advantages and disadvantages of each learning, no best learning model. Researchers to synthesis of literature on the weakness of some models of learning, such as are described in the following Table 3.

The above has been explained one by one drawback associated learning model for Curriculum 2013 models and special learning model PJOK. The weaknesses of the model PJOK teachers need to understand them, because with these flaws PJOK teachers are able to develop to new innovations and combines the advantages of existing models. The purpose of all learning model is easier to help learners in the learning process. In these models clearly have not focused on the learning fun (fun), busy (busy), whole / holistic, and modifications.

\section{CONCLUSIONS}

Based on the initial analysis (need the assessment) above, Researchers will develop a breakthrough model of specialized learning lesson curriculum shades PJOK 2013 to improve the effectiveness of learning as well as providing an alternative PJOK assistance to teachers in implementing the learning process. Learning model that will be developed with different characteristics than other learning models. The learning model PJOK Curriculum 2013 contains characteristics such as fun, busy (busy), whole (holistic), and modification. Therefore, researchers continue research more useful to teachers PJOK such as developing learning models. 
Table 2

Disadvantages Learning Models

\begin{tabular}{|c|c|c|c|}
\hline No & Models of Learning & Weakness Model & Source \\
\hline 1 & Scientific Learning Model & $\begin{array}{l}\text { a. The need for creativity and understanding teachers in the implementation of scientific } \\
\text { learning model; } \\
\text { b. The time required in the process of not understanding learners becomes familiar takes } \\
\text { a long time, making it less efficient; and } \\
\text { c. Difficulties children in using the tool and draw conclusions from an experiment, } \\
\text { learners who are less active, and the habits of learners to acquire knowledge from the } \\
\text { teacher's explanation (teacher-oriented). }\end{array}$ & $\begin{array}{l}\text { Budiyanto, } \\
\text { Waluyo, and } \\
\text { Mokhtar (2016) }\end{array}$ \\
\hline 2 & $\begin{array}{l}\text { Inquiry Learning Model / } \\
\text { Discovery }\end{array}$ & $\begin{array}{l}\text { a. When the students' understanding of the matter at the beginning is not good or do not } \\
\text { understand, it can be frustrating and misconceptions learners; and } \\
\text { b. Knowledge of past learners is not described in the exploration process of the learning } \\
\text { process. }\end{array}$ & Nathan (2004) \\
\hline 3 & $\begin{array}{l}\text { Problem Based Learning } \\
\text { Model }\end{array}$ & $\begin{array}{l}\text { a. Lack of understanding of teachers to problem-based learning; } \\
\text { b. Learners who are concerned with the test results cannot understand the process and } \\
\text { the essence of the problem-based learning; } \\
\text { c. Making the lesson plan created by the teacher to be well prepared, so enthusiastically } \\
\text { of learners can be increased and the learning more enjoyable; } \\
\text { d. The scoring system is complicated and too much of the load time to judge will take a } \\
\text { long time. And will be the more criteria that are not functioning; } \\
\text { e. Much-needed time for the presentation of learning will not be effective and efficient; } \\
\text { and } \\
\text { f. Learners who are unable to adapt to the problem-based learning system will create } \\
\text { stress and decrease the motivation of learners. }\end{array}$ & $\begin{array}{l}\text { Ates \& Eryilmasz } \\
(2011)\end{array}$ \\
\hline 4 & $\begin{array}{l}\text { Project Based Learning } \\
\text { Model }\end{array}$ & $\begin{array}{l}\text { a. Many parents of students who feel disadvantaged, because it adds to the cost of } \\
\text { entering the new system; } \\
\text { b. Many instructors / teachers feel comfortable with the traditional classroom, where } \\
\text { instructors / teachers play a central role in the classroom. This is a difficult transition, } \\
\text { especially for instructors / teachers who have little or no control technologies; } \\
\text { c. Implementing a project-based learning in the classroom may be intimidating to some } \\
\text { teachers who have less experience or novice teachers; } \\
\text { d. Learners who have a weakness in the experiment and collection of information will } \\
\text { have trouble; } \\
\text { e. Learners who are not experienced with working in groups may have difficulty in } \\
\text { negotiation and compromise; and } \\
\text { f. When the topic is given to each of the different groups of learner's fear cannot } \\
\text { understand the topic altogether. Lack of interest of learners in the subject, including } \\
\text { teaching models. }\end{array}$ & Sumarni (2013) \\
\hline 5 & $\begin{array}{l}\text { Cooperative Learning } \\
\text { Model }\end{array}$ & $\begin{array}{l}\text { a. The learning process is still using conventional models; } \\
\text { b. The learning process tends to lead the achievement of the curriculum; and } \\
\text { c. Teachers still following circumstances of learners. }\end{array}$ & $\begin{array}{l}\text { Kristiawan } \\
(2013)\end{array}$ \\
\hline 6 & Learning Model TGFU & $\begin{array}{l}\text { a. The game became the main focus; } \\
\text { b. Spend time observing the learning environment to determine the structure of how and } \\
\text { when to ask questions that are less stressed when teaching more-traditional skills; and } \\
\text { c. Teacher-centered approach used in teaching the game. }\end{array}$ & $\begin{array}{l}\text { Jarrett \& Harvey } \\
(2016)\end{array}$ \\
\hline 7 & Learning Model TPSR & $\begin{array}{l}\text { a. Require a long time to achieve the learning objectives; and } \\
\text { b. Required competent teachers / trained to apply the learning model TPSR. }\end{array}$ & $\begin{array}{l}\text { Escarti et.al } \\
(2012)\end{array}$ \\
\hline 8 & Sport Education Model & $\begin{array}{l}\text { Activities learners who are performing less well on festivity was also followed by the } \\
\text { percentage of teachers who lack activity. This gives a tentative conclusion that the } \\
\text { teacher is less encouraging implementation festivity well in the implementation of Sport } \\
\text { Education (SE) at the end of the championships / competition. }\end{array}$ & $\begin{array}{l}\text { Kurniawan \& } \\
\text { Suherman (2015) }\end{array}$ \\
\hline
\end{tabular}

\section{REFERENCES}

[1] Ates \& Eryilmasz. (2011). Strengths and Weaknesses of Problem-Based Learning in Engineering Education: Students' And Tutors' Perspectives. International Conference on New Horizons in Education, 25, 40-58.

[2] Barkoukis, Taylor, Chanal, \& Ntoumanis. (2014). The Relation between Student Motivation and Student Grades in Physical Education: A 3-Year Investigation. Scand J Med Sci Sports, 24, 406-414.

[3] Budiyanto, M. A.K., Waluyo, L \& Mokhtar, A. (2016). Implementation of Scientific Approach in Education in Primary Education in Malang. Proceeding Biology Education Conference, 13(1), 46-51.

[4] Cuerda, E. A. (2014). Theories and Control Models and Motor Learning: Clinical Applications in Neurorehabilitation. Neurología, 30(1), 32-41.

[5] Derri, Tzetzis, \& Kyriaki (2008). Relationship between Academic Learning Time Physical Education and Skill Concepts Aquisition and Retention. Retrieved 23 July 2019 , from https://www.researchgate.net/publication/259759746.
[6] Haapala, L. (2016). Physical Activity and Sedentary Time in Relation to Academic Achievement in Children. Journal of Science and Medicine in Sport. http://dx.doi.org/10.1016/j.jsams.2016.11.003.

[7] Husain, Hasan, Wahab, \& Jantan, (2015). Determining Teaching Effectiveness for Physical Education Teacher. Procedia - Social and Behavioral Sciences, 172, 733-740.

[8] Ibrahim, A. A. (2015). Comparative Analysis between System Approach, Kemp, and ASSURE Instructional Design Models. International Journal of Education and Research, 3(12), 261-270.

[9] Joyce, B., and Weil, M. (2016). Models of Teaching. Yogyakarta: Pustaka Pelajar.

[10] NASPE, National Association for Sport and Physical Education. (2010). PE Metricse: Assessing National Standards 1-6 in Elementary School. Reston, VA: AAHPERD.

[11] Paturusi, A. (2017). Manajemen Pendidikan Jasmani dan Olahraga. Jakarta: Rineka Cipta.

[12] Regulation of Minister of Education and Culture Number 22 Year 2016 regarding the Standards of Elementary and Secondary Education Processes. Jakarta: Kemdikbud. 
[13] Rink, J. E. (2013). Measuring Teacher Effectiveness in Physical Education. Research Quarterly for Exercise and Sport, 84, 407-418.

[14] Sari, S. M., \& Hartati, S. C. Y. (2013). Efektivitas Pembelajaran Pendidikan Jasmani melalui Pendekatan Modifikasi Permainan Bolavoli. Jurnal Pendidikan Olahraga dan Kesehatan, 1(1), 132-136.
[15] Scruggs, P. W. (2008). Quantifying Physical Activity via Pedometry in Elementary Physical Education. Medicine \& Science in Sports \& Exercise. DOI: 10.1249/01.MSS.0000069748.02525.B2.

[16] Stenescu, M. (2013). Planning Physical Education - From Theory to Practice. Procedia - Social and Behavioral Sciences, 76, 790-794. 